\title{
Do you know this syndrome? ${ }^{*}$
}

\author{
Você conhece esta síndrome?
}

\author{
Luiz Maurício Costa Almeida ${ }^{1}$ \\ Lorena dos Santos Diniz ${ }^{3}$
}

\section{CASE REPORT}

A nine-year-old girl, the daughter of a healthy and non-consanguineous couple, was referred with delayed neuropsychomotor development. Her parents reported no abnormalities and no drug use during pregnancy. Clinical examination revealed low stature and facial asymmetry with the right hemiface smaller than the left one, the maxillary arch and right mandibular arch smaller than the left, right microtia with atresia of the ear canal and a systolic heart murmur grade 1 (Figures 1-3). A depressed scar was also found on the patient's nose at the site of a previous apocrine hidrocystoma. The patient had a normal karyotype (46 XX).

Conventional lumbar spine radiography revealed an incomplete fusion of the posterior elements of S1. Computed tomography of temporal bones showed agenesis of the right external auditory canal and absence of pneumatization of the ipsilateral mastoid air cells, mild hypoplasia of the right ossicular chain,

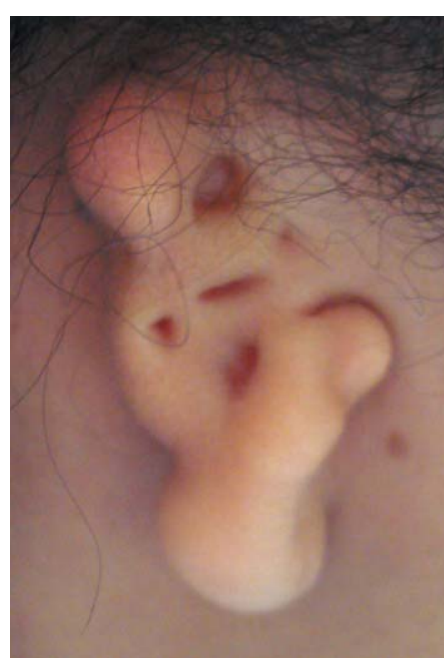

Figure 1: Deformity of the right ear

\author{
Michelle dos Santos Diniz ${ }^{2}$
}

with deformity of the middle ear. Computed tomography of the paranasal sinuses revealed an asymmetry of the jaw and zygomatic bone on the right side. Echocardiogram findings indicated a discrete thickening of the aortic valve with slight regurgitation.

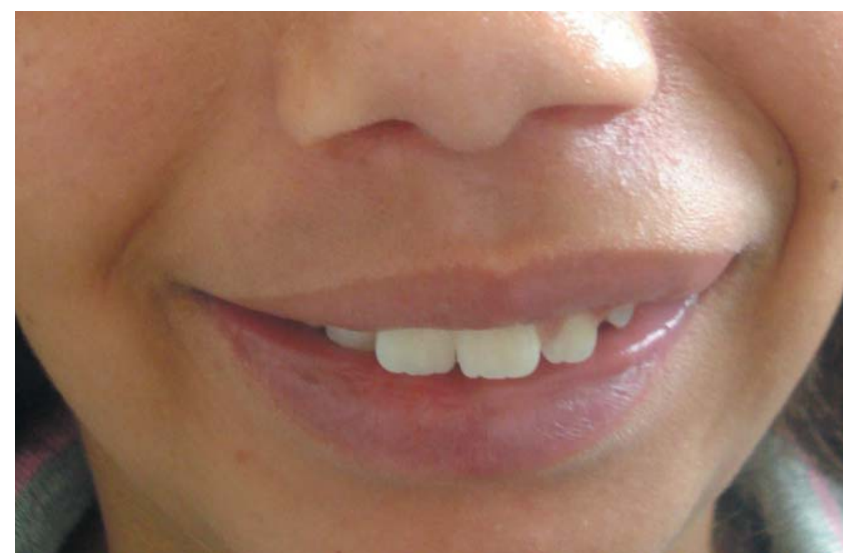

FIGURE 2: Deformity of the jaw

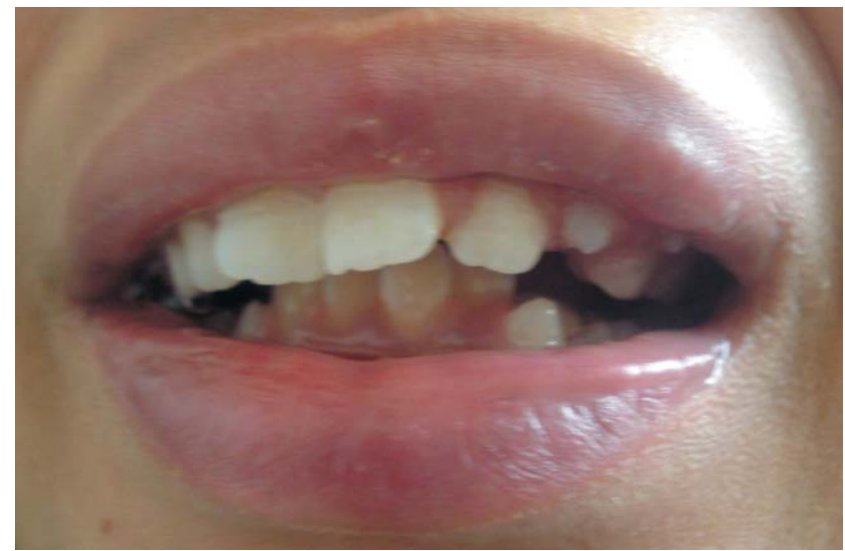

FIGURE 3: Deformity of the teeth

\section{Received on 09.10.2011.}

Approved by the Advisory Board and accepted for publication on 15.01.2012.

* This study was conducted at the Santa Casa de Misericórdia de Belo Horizonte, Belo Horizonte, MG, Brazil.

Conflict of interest: None

Financial funding: None

Dermatologist; Member of the Brazilian Society of Dermatology; Ex-fellow at the University of Colorado (USA) - Preceptor of the Residency Program in Dermatology at the Santa Casa de Misericórdia de Belo Horizonte, Belo Horizonte, MG, Brazil.

Dermatologist; Member of the Brazilian Society of Dermatology; Master's Degree in Public Health awarded by the Federal University of Minas Gerais (UFMG); Preceptor of the Residency Program in Dermatology at the Santa Casa de Misericórdia de Belo Horizonte, Belo Horizonte, MG, Brazil.

General Practice Doctor, Belo Horizonte, MG, Brazil. 


\section{DISCUSSION}

Goldenhar syndrome (oculo-auriculo-vertebral syndrome) is a rare congenital abnormality that involves the first and second branchial arches. ${ }^{1}$ Its incidence varies from 1 in 5,600 to 1 in > 20,000 live births ${ }^{1 .}$ ${ }^{4}$ and it is more common among males, at a proportion of $3: 2 .{ }^{5}$

Its etiology is unknown; however, there are some theories regarding the role played by exposure to viruses or the ingestion of certain drugs such as thalidomide, retinoic acid, tamoxifen and cocaine during pregnancy. It may also be related to abnormal vascular supply to the first and second arch affecting the formation of the vertebral and branchial systems. ${ }^{1,4,5-7}$

Most cases of Goldenhar syndrome are sporadic; however, familial cases have been reported with autosomal dominant inheritance and variable expressivity. Cases with consanguinity between parents have also been reported, suggesting autosomal recessive inheritance.

The classic triad associated with the syndrome includes the presence of limbal dermoids, preauricular skin tags and pretragal fistulas. ${ }^{2}$ Isolated microtia with or without mandibular hypoplasia may also be present or there may be a more complex phenotype with skeletal, cardiac, renal and pulmonary manifestations. ${ }^{4,8}$ Abnormalities of the central nervous system are common among these patients, particularly when ophthalmologic anomalies are present. ${ }^{3}$ These abnormalities are unilateral in $85 \%$ of cases. ${ }^{1}$ Conductive and/or sensorineural hearing loss is present in 50\% of patients with this syndrome. ${ }^{5}$

Limbal dermoids, which consist of benign fibrous tumors at the edge of the cornea, are a typical ocular abnormality in Goldenhar syndrome, and may be unilateral or bilateral. Auricular abnormalities include mild ear malformations, preauricular skin tags, atresia of the external auditory canal, and anomalies in the size and shape of the external auricle. Vertebral skeletal anomalies include occipitalization of the atlas, spina bifida and kyphosis. Cardiac alterations consist of isolated ventricular septal defects or atrial septal defects, pulmonary stenosis and tetralogy of Fallot. With respect to dental and facial abnormalities, facial asymmetry or hemifacial microsomia are always present in patients with this syndrome. ${ }^{2}$

Diagnosis of Goldenhar syndrome should not be based exclusively on x-ray or laboratory findings, but principally on clinical aspects. Ophthalmologic and otorhinolaryngologic evaluations are also important in reaching a definitive diagnosis. ${ }^{6}$

Prognosis is good when there is no mental retardation or cardiac abnormalities. ${ }^{5}$ Treatment depends on the patient's age and systemic manifestations, but generally requires a multidisciplinary approach.

The female patient in this case presented with many of the clinical manifestations of this syndrome including facial asymmetry, right microtia with atresia of the external auditory canal, systolic murmur grade 1 and radiographic findings of skeletal alterations.

It is very important that every physician, including dermatologists, should be able to identify this syndrome given the possibility that other systemic alterations may be present that could affect the patient's prognosis. ${ }^{9} \square$ 
Abstract: Goldenhar syndrome is a sporadic or inherited genetic syndrome characterized by limbal dermoids, preauricular skin tags and mandibular hypoplasia. Vertebral abnormalities may occur. The incidence of this syndrome ranges from 1 in 5,600 to 1 in $>20,000$ live births. It consists of abnormalities involving the first and second branchial arches. The etiology of the syndrome is heterogeneous. Diagnosis should be based principally on clinical aspects, which should be associated with the patient's systemic conditions and radiologic findings. Treatment depends on the patient's age and systemic manifestations, with a multidisciplinary approach often being required.

Keywords: Branchial region; Goldenhar syndrome; Maxillofacial abnormalities

Resumo: A síndrome de Goldenhar é uma síndrome genética esporádica ou hereditária caracterizada por dermóides epibulbares, apêndices auriculares e hipoplasia mandibular. Anormalidades vertebrais podem ocorrer. A sua incidência varia de 1 para 5600 a 20000 nascidos vivos e consiste em anormalidades que envolvem o primeiro e segundo arcos faríngeos. A etiologia da síndrome é heterogênea. O diagnóstico deve ser feito baseado principalmente nos aspectos clínicos e associado tanto com as condições sistêmicas quanto com os achados radiológicos. O tratamento depende da idade e das manifestações sistêmicas geralmente necessitando de acompanhamento multidisciplinar.

Palavras-chave: Anormalidades maxilofaciais; Região branquial; Síndrome de Goldenhar

\section{REFERENCES}

1. Mehta B, Nayak C, Savant S, Amladi S. Goldenhar syndrome with unusual features. Indian J Dermatol Venereol Leprol. 2008;74:254-6.

2. Jena A K, Duggal R. Atypical Goldenhar syndrome: a case report. J Clin Pediatr Dent. 2006;31:118-22.

3. Rosa RF, Graziadio C, Lenhardt R, Alves RP, Paskulin GA, Zen PR. Central nervous system abnormalities in patients with oculo-auriculo-vertebral spectrum (Goldenhar syndrome). Arq Neuropsiquiatr. 2010;68:98-102.

4. Hartsfield JK. Review of the etiologic heterogeneity of the oculo-auriculo-vertebral spectrum (hemifacial microssomia). Orthod Craniofacial Res. 2007;10:121-8.

5. Mahore A, Dange N, Nama S, Goel A. Facio-auriculo-vertebro-cephalic spectrum of Goldenhar syndrome. Neurol India. 2010,58:141-4.

6. Vendramini S, Richieri-Costa A, Guion-Almeida M L. Oculoauriculovertebral spectrum with radial defects: a new syndrome or an estension of the oculoauriculovertebral spectrum? Report of fourteen Brazilian cases and review of the literature. Eur J Hum Genet. 2007:15:411-21.

7. Verona LL, Damian NGC, Pavarina LP, Ferreira CHF, Melo DG. Síndrome de Goldenhar: relato de um caso com discordância em gêmeas monozigóticas. J Pediatr. 2006;82:75-8.
8. Pinheiro AL, Araújo LC, Oliveira SB, Sampaio MC, Freitas AC. Goldenhar's Syndrome - case report. Braz Dent J. 2003;14: 67-70.

9. Paixão MP, Miot HA. Você conhece esta síndrome? Síndrome Oculoauriculovertebral (Síndrome de Goldenhar). An Bras Dermatol. 2007;82: 273-6.

How to cite this article: Almeida LMC, Diniz MS, Diniz LS. Do you know this syndrome? Goldenhar syndrome. An Bras Dermatol. 2012;87(3):495-7. 